\title{
Erratum to: Risk of Upper Gastrointestinal Tract Events in Risedronate Users Switched to Alendronate
}

\author{
Stuart H. Ralston • Tzuyung D. Kou • \\ Bettina Wick-Urban • Michael Steinbuch • \\ Tahir Masud
}

Published online: 24 October 2010

(C) Springer Science+Business Media, LLC 2010

\section{Erratum to: Calcif Tissue Int (2010) 87:298-304 \\ DOI 10.1007/s00223-010-9401-0}

In the article by Ralston et al. (Calcif Tissue Int (2010) 87:298-304; DOI 10.1007/s00223-010-9401-0), it was incorrectly stated in the third paragraph of the results section on page 300 that "In total 30/530 (5.6\%) patients who switched from alendronate to risedronate developed an upper GI event". The correct text should read "In total $30 / 530(5.6 \%)$ patients who switched from risedronate to alendronate developed an upper GI event". This typographical error does not affect any of the data presented or the conclusions of the paper.

The online version of the original article can be found under doi:10.1007/s00223-010-9401-0.

\section{S. H. Ralston ( $\square)$}

Rheumatic Diseases Unit, Institute of Genetics and Molecular Medicine, Western General Hospital, University of Edinburgh,

Edinburgh EH4 2XU, UK

e-mail: stuart.ralston@ed.ac.uk

T. D. Kou · B. Wick-Urban · M. Steinbuch

Procter \& Gamble Pharmaceuticals, Inc., Mason, OH, USA

T. Masud

Nottingham University Hospitals NHS Trust, Nottingham, UK 